Journal of Maternal and Child Health (2018), 3(2): 146-155

https://doi.org/10.26911/thejmch.2018.03.02.07

\title{
Biopsychosocial Determinants of Stunting in Children Under Five: A Path Analysis Evidence from the Border Area West Kalimantan
}

\author{
Eny Indriyani'), Yulia Lanti Retno Dewi²), Harsono Salimo3) \\ ${ }^{1)}$ Masters Program in Public Health, Universitas Sebelas Maret \\ 2)Department of Nutrition, Faculty of Medicine, Universitas Sebelas Maret \\ 3)Department of Pediatrics, Dr. Moewardi Hospital, Surakarta
}

\begin{abstract}
Background: Stunting is a form of nutritional deficiency associated with delayed of children growth and development. Stunting is a lack of linear development due to long-term malnutrition. This study aimed to examine factors associated with stunting in children under-five in West Kalimantan, Indonesia.

Subjects and Method: This was a an analytic observational study with a case-control design. The study was conducted in West Kalimantan, Indonesia. A sample of 200 children under five consisting of 100 stunting children and 100 normal children was selected for this study by fixed disease sampling. The dependent variable was stunting. The independent variables were birth length, maternal education, family income, maternal nutritional intake, maternal middle-upper arm circumference (MUAC), child nutritional intake, and number of children. The data were collected by questionnaire. The data were analyzed by path analysis.

Results: The risk of stunting directly increased with child nutritional intake less than recommended nutritional allowance $(\mathrm{b}=1.61 ; 95 \% \mathrm{CI}=0.86$ to $2.36 ; \mathrm{p}<0.001)$, birth length $<48 \mathrm{~cm}$ $(\mathrm{b}=2.13 ; 95 \% \mathrm{CI}=0.95$ to $3.31 ; \mathrm{p}<0.001)$, and low current maternal education $(\mathrm{b}=1.96 ; 95 \% \mathrm{CI}=$ 1.21 to $2.72 ; \mathrm{p}<0.001)$. The risk of stunting was indirectly and significantly influenced by family income during gestation, number of children, maternal height, maternal MUAC, family support, maternal education during gestation, and maternal nutrition intake during gestation.

Conclusion: The risk of stunting directly increases with child nutritional intakeless than recommended nutritional allowance, birth length $<48 \mathrm{~cm}$, and low current maternal education. The risk of stunting is indirectly and significantly influenced by family income during gestation, number of children, maternal height, maternal MUAC, family support, maternal education during gestation, and maternal nutrition intake during gestation.
\end{abstract}

Keywords: stunting, biopsikososial factors, gestation

\section{Correspondence:}

Eny Indriyani. Masters Program in Public Health, Universitas Sebelas Maret. Jl. Ir. Sutami 36 A, Surakarta, Central Java. Email: zubair.alhafizh@yahoo.com. Mobile:+6282158338438.

\section{BACKGROUND}

Stunting is a form of malnutrition that makes a major global public health concern. The global stunting prevalence by 2016 was $22.9 \%$ or 155 million children under five where as wasting $7.7 \%$ or almost 52 millions children under five (UNICEF/ WHO/ World Bank and Estimates, 2017).

Stunting is a disorder or failure of linear growth occurring in young children which is marks pathological disorder and chronic condition. It represents delayed growth due to long-term malnutrition associated with increased morality and mortality, growth disturbances, developmental disorders and cognitive function. Stunting increases the risk of chronic disease in adulthood (UNICEF/WHO/World Bank, 2016; Briend et al., 2015; De Onis and Branca, 2016).

The prevalence of stunting in Indonesia by 2016 was $27.5 \%$, decreasing from 
previous (2013) reaching 37.2\% (Monitoring Nutritional Status, 2016). Indonesia is included in 17 countries out of 117 countries in the world with child nutritional problems, including stunting, wasting, and overweight. The percentage of short toddlers in Indonesia is still high compared to Myanmar (35\%), Vietnam (23\%), Malaysia (17\%), Thailand (16\%) and Singapore (4\%) (Pusat Data dan Informasi, 2016).

West Kalimantan has 12 districts and 2 administrative cities. Sambas regency is one of the districts located on the northernmost western part of the province of West Kalimantan. The prevalence of stunting in Sambas Regency in 2015 was (38.2\%) and in 2016 was (41.5\%). Sajingan Sub-district is one of the sub-districts in the northern part of Sambas regency, West Kalimantan, which directly borders Sarawak, East Malaysia (Local Government of Sambas Regency, 2015). The prevalence of stunting in 2016 in the area is very high, occupying the first position of 19 districts in Sambas district. The prevalence of stunting in Kecamatan Sajingan In 2014 was (17.68\%), in 2015 was $(28.86 \%)$ and in 2016 was (35.07\%) (Monitoring Nutrition Status of West Kalimantan Province, 2016).

Based on a preliminary survey conducted at the Health Office of Sambas district of West Kalimantan in July 2017, it was recorded that from 767 the number of children under five in sajingan, there were 269 toddlers suffered from stunting (HAZ). According to Motbainor et al. (2015) the fulfillment of inadequate nutrient intake in the form of macro nutrient and micro nutrient during the growth and development since the womb gives a very significant impact on the incidence of stunting.

Maternal education is an indicator of the achievement of child health as well as the fulfillment of child nutrition. The level of maternal education influences the pattern of parenting in the fulfillment of nutritional intake (Stewart et al., 2013; Kusuma, 2013). Poor parenting patterns will affect the fulfillment of children's nutritional intake so that children grow into stunting (Kusuma, 2013). The family income is very influential on the procurement of food needed in the family for the fulfillment of nutritional intake of toddlers (Amin and Julia, 2014).

Family support factors also have a huge impact on stunting cases. Mothers who are depressed in pregnancy can affect the growth and development of the fetus in the womb. The relation found between family support curves in mothers who experienced psychosocial depression during pregnancy with fetal growth and development had an impact on LBW and IUGR (Hobel et al., 2008). Fetal growth and development retardation and lack of nutritional status during pregnancy are very influential on stunting cases of infancy to adulthood (Christian et al., 2013).

The lack of maternal nutrition during pregnancy greatly affects the maternal weight gain and anemia as well as impaired growth and development of the fetus (Harti et al., 2016). Due to lack of energy and protein suffered during pregnancy have a significant effect on the linear growth in infants in the womb described by the size of the baby's body length (Supariasa et al., 2012).

Based on this background and the high number of under-fives suffering from stunting in the border area of West Kalimantan, the authors are interested in further research, especially in analyzing biopsychosocial factors related to stunting cases in infants at the border area of West Kalimantan. The biopsychosocial model is a model used to describe biological, psychological and social factors. Determinants of 
Journal of Maternal and Child Health (2018), 3(2): 146-155

https://doi.org/10.26911/thejmch.2018.03.02.07

disease determinants based on biological causes alone are not sufficient to explain the occurrence of disease processes in the body (Murti, 2016).

\section{SUBJECTS AND METHOD \\ 1. Study Design \\ This was an analytic observational study with a case-control design. The study was conducted in Sajingan sub-district, Sambas district, Kalimantan, with consideration of the area is the border area between Indo- nesia and Sarawak, East Malaysia. The study was conducted in January-February 2018.}

\section{Population and Sample}

The source population in this study was children aged 13-60 months who experienced stunting (HAZ) or normal height living in CHS Sajingan, Sambas district, West Kalimantan Province, Indonesia. A sample of 200 children under five was selected for this study by fixed disease sampling including 100 stunted children and 100 children with normal height.

\section{Study variables}

The dependent variable was stunting. The independent variabels were family income during pregnancy, current family income, maternal middle upper arm circumference (MUAC) during pregnancy, nutritional intake of children, body length at birth, family support, maternal body height, number of children, maternal education during pregnancy, and current maternal education.

\section{Operational definition of variables}

Stunting was defined as a children nutritional status based on body height index by age (HAZ). The measurement scale was continuous. The measurement scale was continuous, but for the purpose data analysis, it was transformed into dichotomous coded $\mathrm{O}$ for normal children and 1 for stunted children.
Family income during pregnancy was defined as an average family income (husband and wife) received per month during pregnancy in the form of money from working that included not only basic salary but also overtime and benefits received regularly during pregnancy. The measurement scale was continuous, but for the purpose data analysis, it was transformed into dichotomous coded o for family income $\geq$ minimum regional wage and 1 for $\geq$ minimum regional wage.

The current family income was defined as the average income of the family (husband and wife) received per month over the six months in the form of money from working that includes not only the basic salary but also including overtime and benefits received regularly now.

Maternal nutritional intake during pregnancy was defined as the amount and type of food consumed by mothers during pregnancy every day in the form of energy intake, protein intake, carbohydrate intake, fat intake as well as additional vitamins and minerals, especially additional iron. The measurement scale was continuous, but for the purpose data analysis, it was transformed into dichotomous coded o for adequate nutrition intake (if < nutritional adequacy rate, NAR) and 1 for inadequate nutrition intake (if $\geq$ Nutritional adequacy rate, NAR).

Children nutrition intake was defined as the amount and type of food consumed by children every day in the form of energy intake, protein intake, carbohydrate intake and fat intake. Total energy needs are derived from nutrient intake such as proteins, carbohydrates and fats in need of toddlers to meet the basal energy needs and to move. The measurement scale was continuous, but for the purpose data analysis, it was transformed into dichotomous. 
Maternal middle upper arm circumference (MUAC) was defined as the size of the maternal upper arm circumference during pregnancy measured using a MUAC tape measure by circling midway between the akromnion (shoulder tip) and the oliganon (elbow) in centimeters. The measurement scale was continuous, but for the purpose data analysis, it was transformed into dichotomous.

Body birth length was defined as the measurement of body length immediately after birth which is measured with supine position. The measurement scale was continuous, but for the purpose data analysis, it was transformed into dichotomous.

Family support during pregnancy was defined as the support or assistance provided by the family in the form of material, motivation, information, and advice. The measurement scale was continuous, but for the purpose data analysis, it was transformed into dichotomous.

Maternal height was defined as maternal stature, classified as short if body height $<150 \mathrm{~cm}$ and normal height if $\geq 150$ $\mathrm{cm}$. The measurement scale was continuous, but for the purpose data analysis, it was transformed into dichotomous.

The number of children was defined as the number of children who lived in a family. The measurement scale was continuous, but for the purpose data analysis, it was transformed into dichotomous.

Maternal education during pregnancy was defined as the last formal education level completed by mother during her pregnancy. Maternal current education was defined as the last formal education level completed by the mother. The measurement scale was categorical.

\section{Study Instrument}

The study instruments used for data collection were questionnaire, mother and child monitoring book, weight scales, and microtoise. The validity test included content and face validity. The reliability test in this study was conducted on 20 children under five in Sajingan sub-district, including 10 stunted children and 10 normal children. The reliability test is performed by calculating total-item correlation $(\geq 0.20)$ and Cronbach alpha $(\geq 0.70)$ using the SPSS statistical program.

\section{Data Analysis}

The data analysis was conducted using path analysis with program Stata 13 to examine direct and indirect effects on the determinants of stunting in children. The steps of path analysis in this research are model specification, model identification, model fit, parameter estimate, and model respesification.

\section{Research Ethics}

The research ethics included informed consent, anonymity, confidentiality and ethical clearance. The ethical clearance in this study was obtained from the Research Ethics Committee Dr. Moewardi hospital, Surakarta, Central Java.

\section{RESULTS \\ 1. Subjects characteristics}

Subjects characteristics in the case group consisted of 100 subjects and the control group also consisted of 100 subjects. The frequency distribution of the subject characteristics is presented in Table 1.

Table 1 shows that 85 study subjects (42.5\%) earned the monthly family income less than minimum wage during pregnancy in 2016. As many as 85 study subjects (42.5\%) earned the current family income less than minimum wage in 2017. 82 mothers (41\%) received maternal nutritional intake during pregnancy $<$ NAR. 100 children (50\%) received nutritional intake $<$ NAR. Maternal MUAC <23.5 cm was 67 mothers (33.5\%). 40 children (20\%) had body birth length $<48 \mathrm{~cm}$. As many as 78 
Journal of Maternal and Child Health (2018), 3(2): 146-155

https://doi.org/10.26911/thejmch.2018.03.02.07

mothers received strong family support (39\%). 93 mothers (46.5\%) had maternal height $<150 \mathrm{~cm} .97$ mothers $(48.5 \%)$ had more than 3 children. 93 mothers (46.5\%) had low education level during pregnancy. 93 mothers (46.5\%) had low current maternal education.

\section{The results of path analysis}

The data were processed using Stata 13 program. Path analysis proceeded in 5 steps: (1) model specification, (2) model identification, (3) model fit, (4) parameter estimation, and (5) model respesification. The number of measured variables was 12 . The endogenous variables were 7 . There were 5 exogenous variables. Degree of

Table 1. Characteristics of study subjects

\begin{tabular}{|c|c|c|}
\hline $\begin{array}{r}\text { Subject characteristics } \\
\end{array}$ & Total (n) & Percent (\%) \\
\hline \multicolumn{3}{|l|}{ Family income during gestation } \\
\hline - Minimum regional wage & 115 & 57.5 \\
\hline - Minimum regional wage & 85 & 42.5 \\
\hline \multicolumn{3}{|l|}{ Current family income } \\
\hline - $\geq$ Minimum regional wage & 115 & 57.5 \\
\hline - < Minimum regional wage & 85 & 42.5 \\
\hline \multicolumn{3}{|c|}{ Maternal nutritional intake during gestation } \\
\hline - Adequate & 118 & 59 \\
\hline - Inadequate & 82 & 41 \\
\hline \multicolumn{3}{|l|}{ Children's nutritional intake } \\
\hline - Adequate & 100 & 50 \\
\hline - Inadequate & 100 & 50 \\
\hline \multicolumn{3}{|l|}{ Maternal MUAC } \\
\hline$-\geq 23.5 \mathrm{~cm}$ & 133 & 66.5 \\
\hline$-<23.5 \mathrm{~cm}$ & 67 & $33 \cdot 5$ \\
\hline \multicolumn{3}{|l|}{ Body birth length } \\
\hline$-\geq 48 \mathrm{~cm}$ & 160 & 80 \\
\hline$-<48 \mathrm{~cm}$ & 40 & 20 \\
\hline \multicolumn{3}{|l|}{ Family support } \\
\hline - Strong & 122 & 61 \\
\hline - Weak & 78 & 39 \\
\hline \multicolumn{3}{|l|}{ Maternal height } \\
\hline$-\geq 150 \mathrm{~cm}$ & 107 & 53.5 \\
\hline$-<150 \mathrm{~cm}$ & 93 & 46.5 \\
\hline \multicolumn{3}{|l|}{ Number of children } \\
\hline - <3 people & 103 & 51.5 \\
\hline$-\geq 3$ people & 97 & 48.5 \\
\hline \multicolumn{3}{|l|}{ Maternal education during gestation } \\
\hline - High $\geq$ Senior high school & 107 & 53.5 \\
\hline - Low < Senior high school & 93 & 46.5 \\
\hline \multicolumn{3}{|l|}{ Current maternal education } \\
\hline - High $\geq$ Senior high school & 107 & 53.5 \\
\hline - Low $<$ Senior high school & 93 & 46.5 \\
\hline
\end{tabular}

freedom $(\mathrm{df})=53$ (over identified). Therefore path analysis could be performed. The structural model with estimation is shown in Figure. 1 and the path analysis results are shown in Table 2. The model in this study is in accordance with the sample data shown by the saturation model and also the regression coefficient which is more than zero and has been statistically significant. Therefore, there is no need to be remade.

Table 2 shows that children nutritional intake <NAR had a logit score for stunting 1.6 units higher than a toddler with nutritional intake $\geq$ NAR $(b=1.61 ; 95 \%$ $\mathrm{CI}=0.86$ to $2.36 ; \mathrm{p}<0.001)$. 


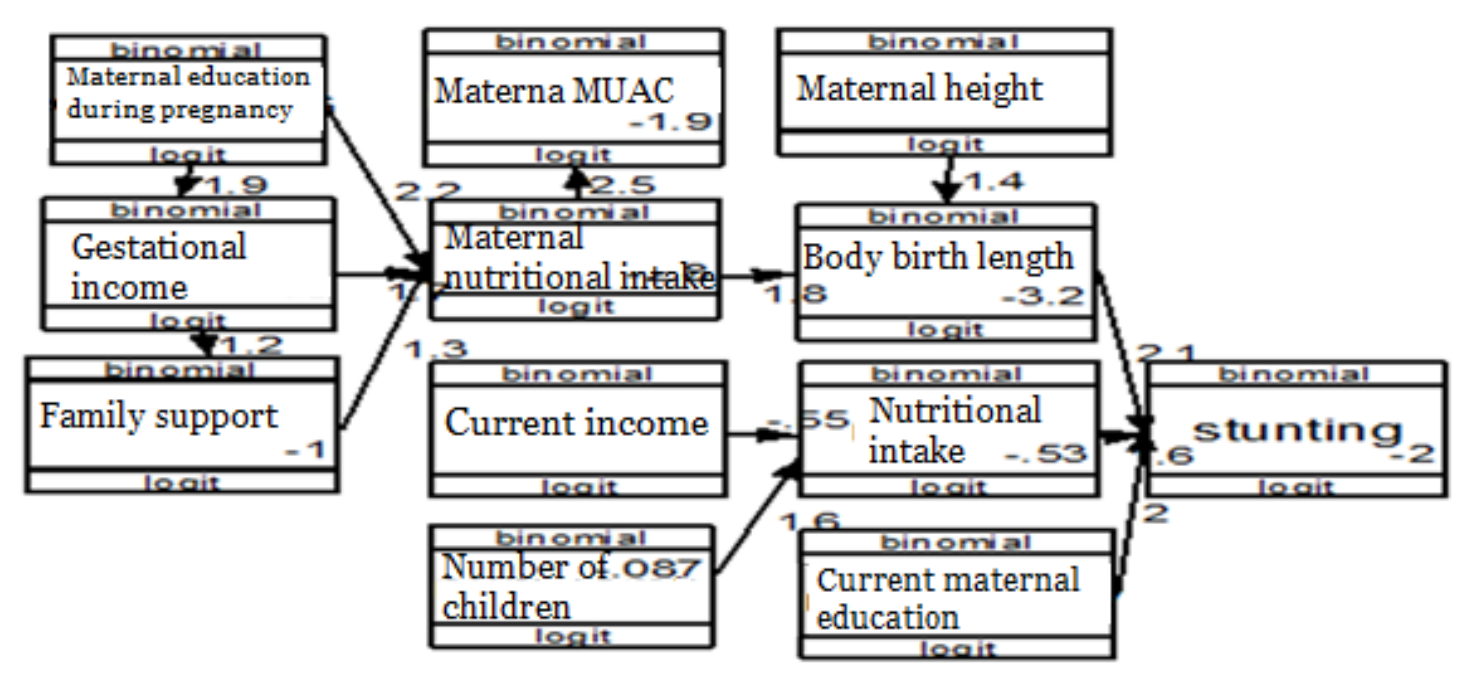

Figure 1. Structural model with estimation

Table 2. The path analysis results of biopsychosocial factor associated with the incidence of stunting in children

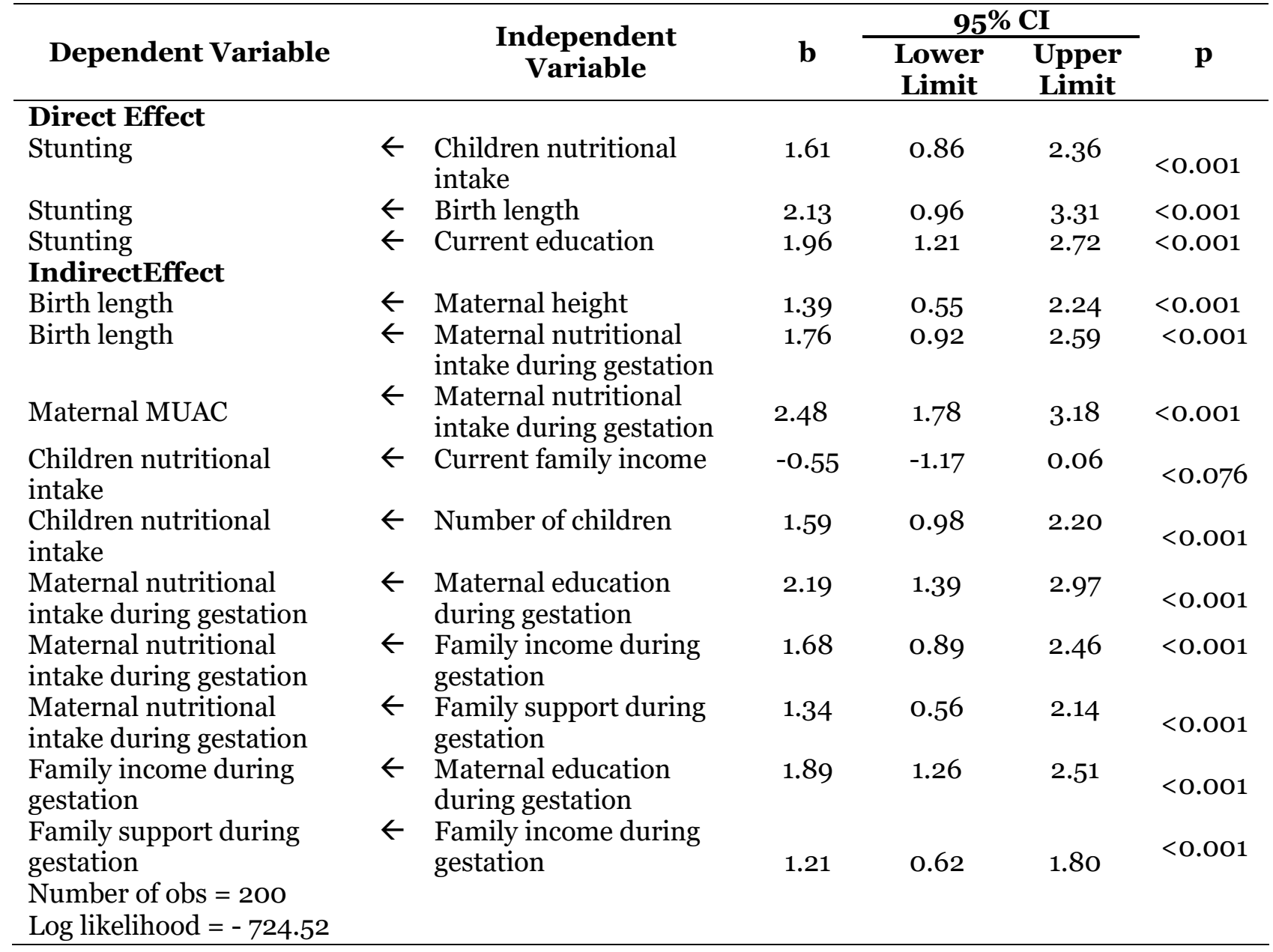

Table 2 shows the results of path analysis on the determinants of stunting in children. Table 2 shows that there was association between body birth length and 
the risk of stunting. Children with body birth length of $<48 \mathrm{~cm}$ increased the likelihood of stunting $(b=2.13 ; 95 \% \mathrm{CI}=$ 0.96 to $3.31 ; \mathrm{p}<0.001$ ).

There was a relationship between current maternal education and the risk of stunting. Low maternal education $<$ Senior high school increased the likelihood of stunting $(b=1.96 ; 95 \% \mathrm{CI}=1.21$ to 2.72 ; $\mathrm{p}<0.001)$.

There was a relationship between maternal height and body birth length. Maternal height $<150 \mathrm{~cm}$ increased the likelihood of body birth length $<48 \mathrm{~cm}$ (b= 1.39; $95 \% \mathrm{CI}=0.55$ to $2.24 ; \mathrm{p}<0.001)$.

There was a relationship between maternal nutritional intake during pregnancy and body birth length. Maternal nutritional intake during gestation $<$ NAR increased the likelihood of body birth length $<48 \mathrm{~cm}(\mathrm{~b}=1.76 ; 95 \% \mathrm{CI}=0.92$ to 2.59; $\mathrm{p}<0.001$ ).

There was a relationship between maternal nutritional intake during pregnancy and maternal MUAC. Maternal nutritional intake during pregnancy $<$ NAR increased the likelihood of maternal MUAC $<23.5 \mathrm{~cm}(\mathrm{~b}=2.48 ; 95 \% \mathrm{CI}=1.78$ to 3.18 ; $\mathrm{p}<0.001$ ).

There was a relationship between current family income and children nutritional intake. Current family income $<$ minimum regional wage decreased good nutrition intake in children $(b=-0.55 ; 95 \%$ $\mathrm{CI}=-1.17$ to $0.06 ; \mathrm{p}<0.076)$.

There was a relationship between the number of children and children nutritional intake. Number of children $\geq 3$ person increased poor children nutritional intake $(b=1.59 ; 95 \% \mathrm{CI}=0.98$ to $2.20 ; \mathrm{p}<0.001)$

There was a relationship between maternal education during gestation and maternal nutritional intake during gestation. Mothers with low education during gestation increased gestational maternal nutritional intake $<$ NAR $(b=2.19$; $95 \% \mathrm{CI}=$ 1.39 to 2.97 ; $<<0.001$ ).

There was a relationship between family income during pregnancy and maternal nutritional intake during gestation. Low family income during pregnancy increased maternal nutritional intake $<$ NAR (b=1.68; 95\% CI $=0.89$ to $2.46 ; \mathrm{p}<$ o.001)

There was a relationship between family support during pregnancy and maternal nutritional intake during pregnancy. Low family support increased maternal nutritional intake $<\mathrm{NAR}(\mathrm{b}=1.34 ; 95 \% \mathrm{CI}=$ 0.56 to 2.14 ; $\mathrm{p}<0.001$ )

There was a relationship between maternal education during pregnancy and family income during pregnancy. Low maternal education increased family income $<$ minimum regional wage $(b=1.89$; $95 \% \mathrm{CI}=1.26$ to $2.51 ; \mathrm{p}<0.001$ )

There was a relationship between family income during pregnancy and family support. Family income during pregnancy $<$ minimum regional wage increased low family support $(b=1.21 ; 95 \% \mathrm{CI}=0.62$ to 1.80; $\mathrm{p}<0.001)$.

\section{The relationship between children nutritional intake and stunting}

The result of this study showed that there was a direct relationship between children nutritional intake and stunting. Inadequate children nutritional intake increased the risk of stunting. The result of this study is consistent with Vazir et al. (2013). A study by Sarma et al. (2017), which was done in Bangladesh showed that children with inadequate nutritional intake were more likely to have stunting.

Goudet et al. (2015) stated that the direct cause of stunting was the lack of nutrient intake fulfillment after the exclusive breastfeeding period, because in 
the process of growing, toddlers need balanced nutritional intake. Physiological disorders and metabolism in infants and toddlers occurred due to inadequate nutrient intake required by the body (Andriani and Wirjatmadi, 2014). In toddler's, the changes of dietary pattern from breast milk into solid foods were occurred, therefore, the toddlers often have difficulty in eating while at this age, they started to interact with the environment. The role of parenting in this period was very important because if the parenting did not work properly, it would give a serious impact on the health of toddlers (Welasih and Wirjatmadi, 2012).

\section{The relationship between body birth length and stunting}

The result of this study showed that there was a direct relationship between birth length and the incidence of stuntingwhich was statistically significant. Toddlers who were born with $<48 \mathrm{~cm}$ birth length have a higher risk of stunting than toddlers who were born with $\geq 48 \mathrm{~cm}$ birth length. This study was in accordance with a study by Ayuningrum et al. (2017) which was done in Purworejo, Central Java, Indonesia. It stated that there was a meaningful relationship between birth length and the incidence of stunting in toddlers.

According to Onis and Branca (2016), birth length was one of the main factors affecting the incidence of stunting. Stunting started from the first 100 days of life due to in-uterine growth disorder. Short birth length reflects the history of protein-energy malnutrition during pregnancy, causing fetal growth retardation (FGR). FGR occurs due to inadequate nutritional intake during gestation, which it leads to short newborn baby (Antum, 2016).

\section{The relationship between current maternal education and stunting}

The result of this study showed that there was a direct relationship between current maternal education and the incidence of stunting which was statistically significant. Mothers with low education (junior high school) have a higher risk of stunting for their toddlers than highly-educated mothers (senior high school). This study was in accordance with a study by Keino et al. (2014) which was done in Sub-Saharan Africa, it showed that maternal education has a direct effect on the incidence of stunting. A study by Wolde et al. (2015) which was conducted in Dale Woreda, South Ethiopia stated that children who have loweducated mothers were more likely to experience stunting compared to children with highly-educated mothers. A study by Rahmawati et al. (2017) which was done in Jombang, East Java, Indonesia showed that there was a direct effect between current maternal education and the incidence of stunting.

Mother with high education level has the ability to make choices in the practice of changing child dietary care (Goudet et al., 2015). High educated mother more easy to receive information from outside, especially on how to take care of children, cultivate food and fulfillment of nutritional intake, both quality and quantity needed by children properly, able to plan the nutritional intake for herself and her family, able to know the relationship between nutritional intake needs with health, or body needs needed in the fulfillment of nutrients in family members and have the ability to apply the knowledge of nutrition and good parenting compared to low-educated mother (Kusuma and Nuryanto, 2013; Andriani and Wirjatmadi, 2014).

Based on the study, it can be concluded that the risk of stunting was directly related to the children nutritional intake which was less than nutritional adequacy ratio, body birth length $<48 \mathrm{~cm}$, and current maternal education $<$ Senior high 
school. The risk of stunting was indirectly and significantly due to maternal education during gestation, family income during gestation, family support during gestation, maternal MUAC, maternal nutritional intake during gestation, current family income, the number of children in the family, and maternal height.

\section{CONFLICT OF INTEREST}

Nothing declared.

\section{REFERENCES}

Amin NA, Julia M (2014). Faktor sosiodemografi dan tinggi badan orang tua serta hubungannya dengan kejadian stunting pada balita usia 6-23 bulan. Jurnal Gizi dan Dietetik Indonesia. 2(3): 174-80.

Andriani M, Wirjatmadi B (2014). Gizi dan kesehatan balita (peranan mikro zinc pada pertumbuhan balita). Jakarta: Kencana Prenadamedia Group.

Ayuningrum IY, Salimo H, Dewi YLR (2017). Path analysis on gestational socio-economic determinants of nutritional status in children under five in Purworejo Regency, Central Java. Journal of Maternal and Child Health. 2(1): 30-41

Badan Penelitian Pengembangan Pertanian. Profil Kemandirian Pangan Wilayah Perbatasan Kalimantan Barat. diakses tanggal 5 Nopember 2017. http://www.litbang.pertanian.go.id/buku/membangun.

Briend A, Khara T, Dolan C (2015). Wasting and stunting-similarities and differences: policy and programmatic implications. Food and Nutrition Bulletin 36: S15-23.

Chistian P, Lee ES, Angel DM, Adair SL, Arifeen ES, Ashorn P, Barros F, et al (2013). Risk of childhood undernutrition related to small-for-gestational age and preterm birth in low- and middle-income countries. International Journal of Epidemiology. 42(5): 1340-1355.

Dewan Ketahanan Pangan, World Food Programe (2015). Peta ketahanan pangan dan kerentanan pangan Indonesia. Jakarta.

Goudet MS, Griffiths LP, Bogin AB, Madise JN (2015). Nutritional interventions for preventing stunting in children (o to 5 years) living in urban slums. Cochrane Public Health Group.5.

Harti BL, Kusumastuty I, Hariadi I (2016). Hubungan status gizi dan pola makan terhadap penambahan berat badan ibu hamil. Indonesian Journal of Human Nutrition. 3 (1)54-62.

Hobel JC, Goldstein A, Barrett SE (2008). Psychosocial stress and pregnancy outcome. Clinical Obstetrics And Gynecology. 51(2), 333-348.

Keino S, Plasqui G, Ettyang G, Borne DVB (2014). Determinants of stunting and overweight among young children and adolescents in sub-Saharan Africa. Food and Nutrition Bulletin. 35(2).

Kusuma EK, Nuryanto (2013). Faktor risiko kejadian stunting pada anak 2-3 tahun (studi di Kecamatan Semarang Timur). Journal of Nutririon College 2(4): 523-30.

Murti B (2016). Prinsip dan metode riset epidemiologi. Program Studi Ilmu Kesehatan Masyarakat. Program Pascasarjana, Universitas Sebelas Maret: Yuma Pustaka.

Motbainor A, Worku A, Kumie A (2015). Stunting is associated with food diversity while wasting with food insecurity among underfive children in East And West Gojjam Zones Of Amhara Region, Ethiopia. Plos One. 14(1). 
Pemantauan Status Gizi provinsi Kalimantan Barat 2016.

Pemerintah Daerah Kabupaten Sambas, (2017). Profil daerah Kabupaten Sambas. diakses 19 September 2017. https://id.wikipedia.org/wiki/Kabupaten_Sambas.

Pusat Data dan Informasi (2016). Situasi balita pendek. Jakarta.

Rahmawati EV, Pamungkasari PE, Murti B (2017). Determinants of stunting and child development in Jombang District. Journal of Maternal and Child Health (2018), 3(1): 68-80.

Sarma H, Khan RJ, Asaduzzaman M, Uddin F, Tarannum S, Hasan M, Rahman SA, Ahmed T (2017). Factors influencing the prevalence of stunting among children aged below five years in Bangladesh. Food and nutrition bulletin. 38-3.

Stewart PC, Iannotti L, Dewey GK, Michaelsen FK, Onyango WA (2013). Contextualising complementary feeding in a broader framework for stunting prevention. Maternal \& Child Nutrition, 9; 27-45
UNICEF/WHO/World Bank Group, Estimates JC (2017). Levels and trends in child malnutrition edition.

Vazir S, Engle P, Balakrishna N, Griffiths PL, Johnson SL, Creed-Kanashiro H, Fernandez Rao S, Shroff MR, Bentley ME (2013). Cluster-randomized trial on complementary and responsive feeding education to caregivers found improved dietary intake, growth and development among rural Indian toddlers. Matern Child Nutr. 9(1): 99117.

Welasasih BD, Wirjatmadi RB (2012). Beberapa faktor yang berhubungan dengan status gizi balita stunting. The Indonesian Journal of Public Health 8(3): 99-104.

Wiyogowati C (2012). Kejadian stunting pada anak berumur dibawah lima tahun (0-59 bulan) di Propinsi Papua Barat tahun 2010 (Analisis Data Riskesdas 2010)" FKM UI.

Wolde M, Berhan Y, Chala A (2015). Determinants of underweight, stunting and wasting among school children. BMC Public Health. 15:8 